\title{
Reductive Dissolution of Spinel-Type Iron Oxide by $\mathrm{N}_{2} \mathrm{H}_{4}-\mathrm{Cu}(\mathrm{I})-\mathrm{HNO}_{3}$
}

\author{
Hui Jun Won ${ }^{1} \dagger$, Na On Chang, Sang Yoon Park, and Seon Byeong Kim \\ Decommissioning Technology Research Division, Korea Atomic Energy Research Institute, Daejeon 34057, Korea
}

(Received June 17, 2019; Revised July 2, 2019; Accepted July 5, 2019)

\begin{abstract}
A $\mathrm{N}_{2} \mathrm{H}_{4}-\mathrm{Cu}(\mathrm{I})-\mathrm{HNO}_{3}$ solution was used to dissolve magnetite powders and a simulated oxide film on Inconel 600 . The addition of $\mathrm{Cu}(\mathrm{I})$ ions to $\mathrm{N}_{2} \mathrm{H}_{4}-\mathrm{HNO}_{3}$ increased the dissolution rate of magnetite, and the reaction rate was found to depend on the solution $\mathrm{pH}$, temperature, and $\left[\mathrm{N}_{2} \mathrm{H}_{4}\right]$. The dissolution of magnetite in the $\mathrm{N}_{2} \mathrm{H}_{4}-\mathrm{Cu}(\mathrm{I})-\mathrm{HNO}_{3}$ solution followed the contracting core law. This suggests that the complexes of $\left[\mathrm{Cu}^{+}\left(\mathrm{N}_{2} \mathrm{H}_{4}\right)\right]$ formed in the solution increased the dissolution rate. The dissolution reaction is explained by the complex formation, adsorption of the complexes onto the surface ferric ions of magnetite, and the effective electron transfer from the complexes to ferric ions. The oxide film formed on Inconel 600 is satisfactorily dissolved through the successive iteration of oxidation and reductive dissolution steps.
\end{abstract}

Key words : Spinel, Inconel 600, Cuprous ion, Hydrazine

\section{Introduction}

$\mathrm{M}$ agnetite $\left(\mathrm{Fe}_{3} \mathrm{O}_{4}\right)$ has a spinel structure. Its unit cell contains 32 cation octahedral sites and 64 tetrahedral sites. One eighth of the tetrahedral sites and one fourth of the octahedral sites are occupied by trivalent Fe ions, and one fourth of the octahedral sites are occupied by divalent Fe ions. ${ }^{1)} \mathrm{Ni}$, Cr-substituted magnetite is the main iron oxide that forms on the surface of iron-based metals, especially when in contact with the coolants used in pressurized water reactors (PWRs). The best way to remove radionuclides such as Co-60 in the oxide layer is to dissolve the oxide without affecting the base metal.

Many solution formulations have been developed to decontaminate the internal loops of nuclear power plants. A formulation consisting of nitrilotriacetic acid (NTA) and hydrazine at high temperature $\left(160^{\circ} \mathrm{C}\right)$ was optimized and tested for its efficiency for dissolving oxides formed under boiling water reactor (BWR) conditions on SS-304 surfaces. ${ }^{2)}$ This NTA-hydrazine formulation at $160^{\circ} \mathrm{C}$ could dissolve the oxides in a single step. Rodenas et al. measured the dissolution rates of $\mathrm{NiO}, \mathrm{CoO}, \mathrm{ZnO}$, and $\mathrm{Fe}_{2} \mathrm{O}_{3}$ and their corresponding ferrites in oxalic acid at $70^{\circ} \mathrm{C}$. ${ }^{3)}$ The dissolution of simple oxides proceeded through the formation of surface metal oxalate complexes, followed by the transfer of surface complexes. They concluded that the most important factor determining the rates of dissolution of metal oxides was the lability of metal-oxygen bonds. Keny et al. evaluated the

Corresponding author : Hui Jun Won

E-mail : nhjwon@kaeri.re.kr

Tel : +82-42-868-2331 Fax : +82-42-868-4797

ORCID

https://orcid.org/0000-0002-8833-7526 effects of radiation on the dissolution kinetics of magnetite and hematite in ethylenediaminetetraacetic acid (EDTA)based and NTA-based dilute chemical-decontamination formulations. ${ }^{4)}$ EDTA-based formulations were more efficient for dissolving iron oxides than NTA-based formulations in unirradiated solutions. They also reported that the efficiency of dissolution was affected to a much greater extent in formulations containing EDTA and ascorbic acid compared with those containing NTA and gallic acid.

The dissolution of magnetite particles in solutions containing EDTA and Fe(II) was studied as a function of the total concentrations of EDTA and Fe(II).5) The results were interpreted in terms of fast solution and surface complexation processes, followed by slow heterogeneous electron transfer from adsorbed $\mathrm{FeY}^{2-}$ to surface $>\mathrm{Fe}$ (III) centers and fast phase transfer of $>\mathrm{Fe}$ (II). The inhibitory effect of excess EDTA was also found to result from the competitive adsorption of $\mathrm{FeY}^{2-}$ and EDTA. Segal and Sellers studied the reactions of solid iron oxides with aqueous reducing agents. ${ }^{6)}$ The reaction of $\mathrm{Fe}_{2} \mathrm{O}_{3}$ with $\mathrm{V}$ (pic) ${ }_{3}{ }^{-}$was too rapid to be measured via sampling methods. They reported that one-electron reducing agents dissolved oxides containing $>\mathrm{Fe}$ (III), including insoluble nickel ferrite, and that the mechanisms of such reactions could be interpreted by analogy with homogeneous electron-transfer reactions. It is interesting to note that metal ions enhance dissolution in a way that is related to both its ability for complexation with ligands and the reducing power of surface $>\mathrm{Fe}$ (III) centers. Hydrazine not only acts as a reducing agent of metal ions but also forms a coordination compound with them. Furthermore, hydrazine is decomposed easily into nitrogen and water by hydrogen peroxide.

The objective of this study is to evaluate the dissolution capability of $\mathrm{N}_{2} \mathrm{H}_{4}-\mathrm{Cu}(\mathrm{I})-\mathrm{HNO}_{3}$ on spinel-type oxides, such 
as magnetite, and the oxide film that forms on the surface of Inconel 600. The probable reactions involved in the dissolution of magnetite are also suggested.

\section{Experimental Procedure}

\subsection{Magnetite dissolution}

All the chemicals used in this study were of AR/GR grade, and all solutions were made in demineralized water. The synthesis of magnetite was initiated by precipitating ferrous ammonium sulfate at a $\mathrm{pH}$ of 11 using $\mathrm{NaOH}$. The resulting hydroxide was calcined at $800^{\circ} \mathrm{C}$ in an inert atmosphere for $10 \mathrm{~h}$. The prepared samples were thoroughly ground in an agate mortar and were characterized via X-ray diffraction (XRD) spectroscopy. Experiments on magnetite dissolution were carried out in a magnetically stirred Erlenmeyer flask on a hot plate. In all experiments, an amount of magnetite equivalent to $6.6 \times 10^{-4} \mathrm{M}$ (35.5 ppm) of iron was employed. Hydrazine monohydrate was used as the main dissolution agent; $65 \% \mathrm{HNO}_{3}$ for $\mathrm{pH}$ control and $\mathrm{Cu}\left(\mathrm{NO}_{3}\right)_{2} \cdot 3 \mathrm{H}_{2} \mathrm{O}$ were used as received. The solution was de-aerated for $30 \mathrm{~min}$ via bubbling with highly pure $\mathrm{N}_{2}$ gas. To prevent changes in mass transfer, all experiments were carried out at a constant stirring speed. The amounts of iron ions dissolved in the solutions were determined via atomic absorption analysis.

\subsection{Identification of copper hydrazine complexes}

The addition of $4.0 \mathrm{~g}$ of $\mathrm{CuCl}_{2}$ to a solution of $2.4 \mathrm{~g}$ of $\mathrm{N}_{2} \mathrm{H}_{4}$ in $11 \mathrm{ml}$ of $1-\mathrm{M} \mathrm{HCl}$ produced an immediate light-green precipitate solution. Copper(I) hydrazine complexes were synthesized at $90^{\circ} \mathrm{C}$ for $10 \mathrm{~min}$ in a reduction atmosphere via a hydrothermal process. Because the synthesized compound oxidized easily in air, it was treated carefully. Analysis was performed using a far Fourier transform infrared (FT-IR) absorption spectrometer. The IR spectra of the complexes were recorded in the wavenumber range between 340 and $3400 \mathrm{~cm}^{-1}$.

\subsection{Oxide film dissolution}

Coupons $\left(\sim 7.6 \mathrm{~cm}^{2}\right)$ of Inconel 600 polished up to 600 grit/ P1200 using silicon carbide paper on an automatic grinder were used for the formation of the oxide film. A 4.5-L semiloop was filled with an aqueous solution containing $\mathrm{LiOH}$ (2.2 mg/L of Li), $\mathrm{H}_{3} \mathrm{BO}_{3}(650 \mathrm{mg} / \mathrm{L}$ of $\mathrm{B})$, and $\mathrm{N}_{2} \mathrm{H}_{4}(90 \mathrm{mg} / \mathrm{L})$. Coupons were placed in the semi-loop and the solution was circulated at $350^{\circ} \mathrm{C}$ for 30 days. The pressure in the semiloop was 2700 psi and the dissolved oxygen concentration was maintained at $10 \mathrm{ppb}$. XRD analysis of the oxide film scraped from the Inconel 600 coupons indicated that the produced film was essentially made of spinel-structured nickel chromium ferrite. The coupons were also treated with a solution containing $\mathrm{HNO}_{3}(0.32 \mathrm{~g} / \mathrm{L})$ and $\mathrm{KMnO}_{4}(1.0 \mathrm{~g} / \mathrm{L})$ at $95^{\circ} \mathrm{C}$ for $12 \mathrm{~h}$ before the reductive dissolution step. The amounts of dissolved iron ions in the reductive dissolution step and chromium ions in the oxidation step were analyzed.
The surface morphology of the coupons was investigated via scanning electron microscopy (SEM) before and after the dissolution tests.

\section{Results and Discussion}

\subsection{Magnetite dissolution}

Figure 1 shows a plot of the dissolved fraction of magnetite vs. time under various $\left[\mathrm{N}_{2} \mathrm{H}_{4}\right]$ at $95^{\circ} \mathrm{C}$. The reproducibility of the dissolution data was within $\pm 2.8 \%$. As shown in Fig. 1, the dissolved fraction of magnetite increased as $\left[\mathrm{N}_{2} \mathrm{H}_{4}\right]$ in an acid solution increased. It took $6 \mathrm{~h}$ to dissolve the magnetite completely when $\left[\mathrm{N}_{2} \mathrm{H}_{4}\right]$ was $0.07 \mathrm{M}$. This result is similar to that obtained for the dissolution kinetics of magnetite in EDTA- and NTA-based dilute chemical formulations. ${ }^{4)}$ Keny et al. reported that it took longer than $5 \mathrm{~h}$ to completely dissolve magnetite when the $\mathrm{pH}$ of the solution was $2.7-2.8$ at $80^{\circ} \mathrm{C}$. Baumgartner et al. ${ }^{7)}$ proposed that the reductive dissolution of magnetite can be expressed as shown in Eq. (1).

$$
\mathrm{Fe}_{3} \mathrm{O}_{4}+8 \mathrm{H}^{+}+2 \mathrm{e}^{-} \rightarrow 3 \mathrm{Fe}^{2+}+4 \mathrm{H}_{2} \mathrm{O}
$$

Two explanations are possible in the $\mathrm{N}_{2} \mathrm{H}_{4}-\mathrm{Cu}(\mathrm{I})-\mathrm{H}^{+}$system. 1) Hydrazine itself is a reducing agent that can be used in an acid atmosphere to directly reduce the surface ferric ions of magnetite. 2) Hydrazine can also behave as a reducing agent of $\mathrm{Cu}(\mathrm{II})$ ions, and then $\mathrm{Cu}(\mathrm{I})$ ions efficiently reduce the surface ferric ions of magnetite.

A contracting core law of the form shown in Eq. (2) was found, where $f$ is the fraction of dissolved iron in magnetite at time $t$ and $k$ is the apparent rate constant.

$$
1-(1-f)^{1 / 3}=k t
$$

This law can be derived from the assumption that the dissolution rate is proportional to the instantaneous surface area and from an approximation of considering uniform and spherical particles. A plot of $1-(1-f)^{1 / 3}$ vs. time under various $\left[\mathrm{N}_{2} \mathrm{H}_{4}\right]$ at $95^{\circ} \mathrm{C}$ is shown in Fig. 2. As shown in the figure, deviation from linearity occurs during the reaction

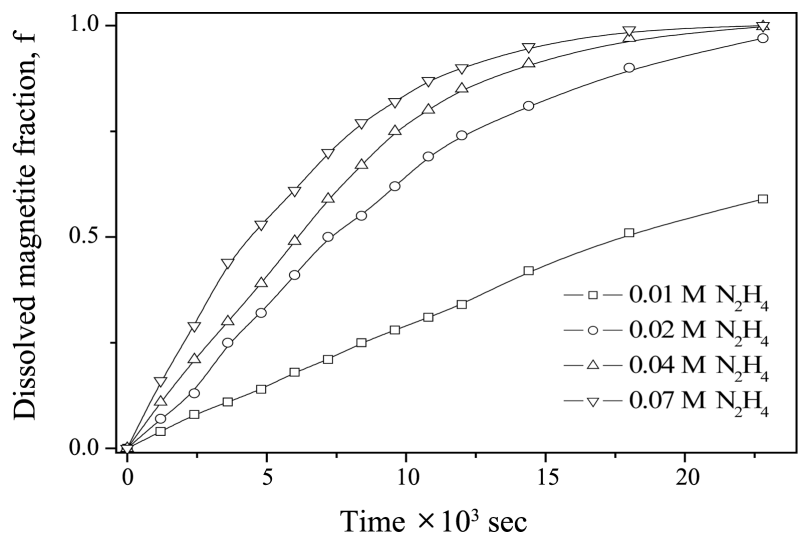

Fig. 1. Dissolved fraction of magnetite (f) as a function of time at different $\left[\mathrm{N}_{2} \mathrm{H}_{4}\right], \mathrm{pH}=3, \mathrm{~T}=95^{\circ} \mathrm{C}$ and $\left[\mathrm{Cu}^{+}\right]=$ $5 \times 10^{-4} \mathrm{M}$. 


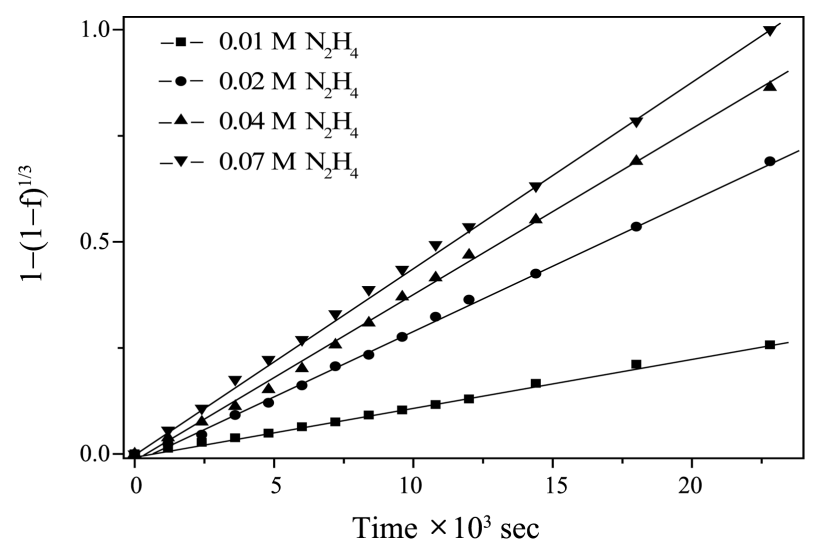

Fig. 2. $1-(1-\mathrm{f})^{1 / 3}$ as a function of time at different $\left[\mathrm{N}_{2} \mathrm{H}_{4}\right]$, $\mathrm{pH}=3, \mathrm{~T}=95^{\circ} \mathrm{C}$ and $\left[\mathrm{Cu}^{+}\right]=5 \times 10^{-4} \mathrm{M}$.

period, except for the $0.01 \mathrm{M} \mathrm{N}_{2} \mathrm{H}_{4}$ system. The dissolution rate of magnetite increased with initial [Fe(II)] in EDTA, ethylenediaminedisuccinic acid (EDDS), and $\mathrm{H}_{2} \mathrm{SO}_{4}$ base solutions under the given conditions. ${ }^{5,8,9)}$ After interpreting these results, Borghi et al. concluded that a faster rate could be achieved at an [EDTA] : [Fe(II)] ratio significantly larger than 1 .5) $^{5}$ The observed deviation from linearity may be explained by the increase of the dissolution rate caused by $\mathrm{Fe}(\mathrm{II})$ ions generated via the dissolution of magnetite. The presence of non-spherical magnetite particles cannot be excluded. Al-Mayouf et al. found that the dissolution rate of magnetite in EDDS solutions decreased with time. ${ }^{8)}$ They suggested that the drop in the dissolution rate was due to the decrease in the surface area of dissolving particles. Fig. 2 shows linear correlations over the entire reaction time. This linearity is based on the control of surface chemical reactions for the dissolution of magnetite caused by the hydrazine base solution.

The effects of solution temperature on the dissolution of magnetite were investigated at $\left[\mathrm{N}_{2} \mathrm{H}_{4}\right]=0.02 \mathrm{M}$ and a $\mathrm{pH}$ of 3. A plot of the dissolved fraction of magnetite vs. time under various temperatures is shown in Fig. 3. When the

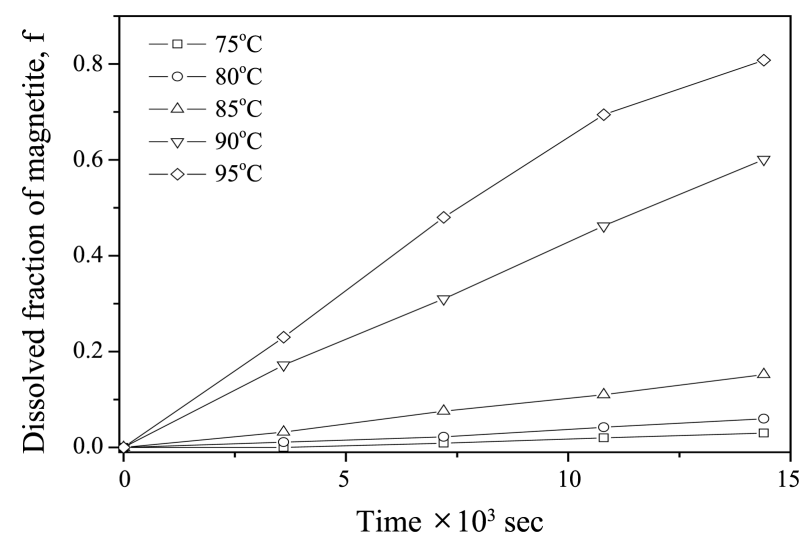

Fig. 3. Dissolved fraction of magnetite (f) as a function of time at different temperatures, $\left[\mathrm{N}_{2} \mathrm{H}_{4}\right]=0.02 \mathrm{M} \mathrm{pH}=$ 3 and $\left[\mathrm{Cu}^{+}\right]=5 \times 10^{-4} \mathrm{M}$.

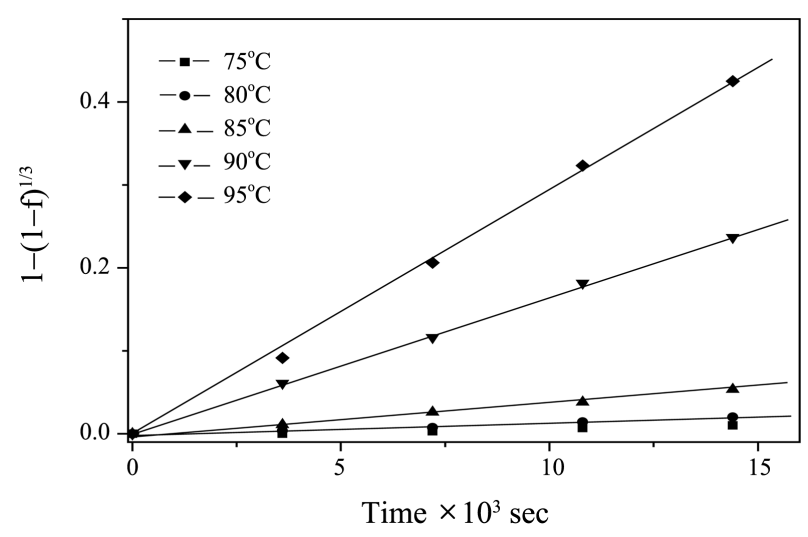

Fig. 4. $1-(1-\mathrm{f})^{1 / 3}$ as a function of time in the temperature range from 75 to $95^{\circ} \mathrm{C},\left[\mathrm{N}_{2} \mathrm{H}_{4}\right]=0.02 \mathrm{M}, \mathrm{pH}=3$ and $\left[\mathrm{Cu}^{+}\right]=5 \times 10^{-4} \mathrm{M}$.

temperature was below $90^{\circ} \mathrm{C}$, magnetite hardly dissolved. After a given time, the dissolved iron fraction was found to increase with solution temperature. After $4 \mathrm{~h}$, more than $81 \%$ of the magnetite had dissolved at $95^{\circ} \mathrm{C}$.

A plot of $1-(1-\mathrm{f})^{1 / 3}$ vs. time in the temperature range from $75^{\circ} \mathrm{C}$ to $95^{\circ} \mathrm{C}$ at $0.02 \mathrm{M}\left[\mathrm{N}_{2} \mathrm{H}_{4}\right]$ is shown in Fig. 4. The dissolution rate was observed to be highly dependent on temperature because the $k$ values steeply increased as temperature increased. The apparent rate constant $k$ obtained for magnetite dissolution at various $\left[\mathrm{N}_{2} \mathrm{H}_{4}\right]$ and temperature ranges are listed in Table 1 . The obtained $k$ values show that the dissolution rate depends on $\left[\mathrm{N}_{2} \mathrm{H}_{4}\right]$ and temperature in the presence of $5 \times 10^{-4} \mathrm{M}[\mathrm{Cu}(\mathrm{I})]$ at a $\mathrm{pH}$ of 3 .

The effect of $[\mathrm{Cu}(\mathrm{I})]$ and solution $\mathrm{pH}$ on the dissolution of magnetite was investigated. Fig. 5 shows the fraction of magnetite that had dissolved over the $6 \mathrm{~h}$ of reaction against $[\mathrm{Cu}(\mathrm{I})]$ at a constant $\left[\mathrm{N}_{2} \mathrm{H}_{4}\right]$ and $95^{\circ} \mathrm{C}$. At a $\mathrm{pH}$ of 2 , the dissolved fraction of magnetite increased slowly as $[\mathrm{Cu}(\mathrm{I})]$ increased from 0 to $2.0 \times 10^{-3} \mathrm{M}$. Above $2.0 \times 10^{-3} \mathrm{M}$, the dissolved fraction of magnetite for any given time did not increase. At a pH of 3, the dissolved fraction of magnetite increased steeply as $[\mathrm{Cu}(\mathrm{I})]$ increased from 0 to $2.5 \times$ $10^{-4} \mathrm{M}$. Above $2.5 \times 10^{-4} \mathrm{M}$, the dissolved fraction of magnetite did not increase. Unlike the results for a $\mathrm{pH}$ of 2 , under a $\mathrm{pH}$ of 3 , magnetite was fully dissolved when $[\mathrm{Cu}(\mathrm{I})]$

Table 1. Apparent Rate Constant k Obtained for Magnetite Dissolution at $\mathrm{pH} 3$

\begin{tabular}{cccc}
\hline$\left[\mathrm{N}_{2} \mathrm{H}_{4}\right] / \mathrm{M}^{-1}$ & ${ }^{\circ} \mathrm{C}$ & {$\left[\mathrm{Cu}^{+}\right] / 10^{4} \mathrm{M}^{-1}$} & $\mathrm{k} / 10^{5} \mathrm{~s}^{-1}$ \\
\hline 0.01 & 95 & 5 & 0.13 \\
0.02 & 95 & 5 & 2.93 \\
0.04 & 95 & 5 & 3.80 \\
0.07 & 95 & 5 & 4.32 \\
0.02 & 75 & 5 & 0.09 \\
0.02 & 80 & 5 & 0.15 \\
0.02 & 85 & 5 & 0.39 \\
0.02 & 90 & 5 & 1.65 \\
\hline
\end{tabular}




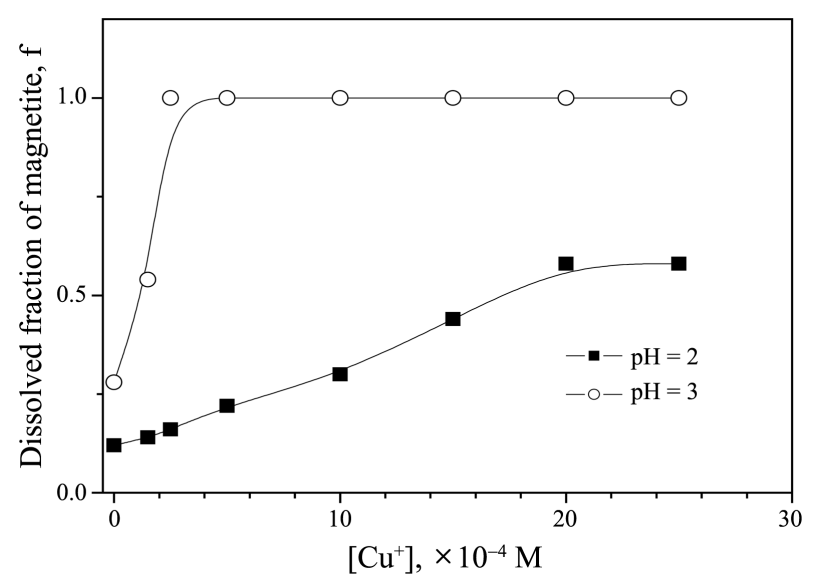

Fig. 5. Dissolved fraction of magnetite (f) over 6 h' reaction as a function of $\left[\mathrm{Cu}^{+}\right]$at $\mathrm{pH} 2$ and $3,\left[\mathrm{~N}_{2} \mathrm{H}_{4}\right]=0.07 \mathrm{M}$ and $\mathrm{T}=95^{\circ} \mathrm{C}$.

exceeded $2.5 \times 10^{-4} \mathrm{M}$. A total of $58 \%$ of the magnetite, however, dissolved over $6 \mathrm{~h}$ at a $\mathrm{pH}$ of 2 .

The effect of $[\mathrm{Cu}(\mathrm{I})]$ on the dissolution of magnetite can be interpreted in terms of the following hydrolysis reaction: ${ }^{10)}$

$$
2 \mathrm{Cu}^{+}+\mathrm{H}_{2} \mathrm{O} \rightarrow \mathrm{Cu}_{2} \mathrm{O}+2 \mathrm{H}^{+}, \log \left[\mathrm{Cu}^{+}\right]=-0.84-\mathrm{pH}
$$

where $\mathrm{Cu}_{2} \mathrm{O}_{(\mathrm{s})}$ represents cuprous oxide. The concentration of soluble cuprous ions decreases as solution $\mathrm{pH}$ increases. Theoretically, the maximum $[\mathrm{Cu}(\mathrm{I})]$ at $\mathrm{pH} 3$ is $1.45 \times 10^{-4} \mathrm{M}$ and at $\mathrm{pH} 2$ is $1.45 \times 10^{-3} \mathrm{M}$. A hydrolysis reaction from the red-colored cubic-structured oxide to yellow-colored $\mathrm{Cu}(\mathrm{OH})$ also occurs. Although a quantitative explanation is difficult, soluble $\mathrm{Cu}(\mathrm{I})$ ions greatly increase the dissolution rate of magnetite below a certain concentration for the given solution $\mathrm{pH}$ values.

The effects of $\mathrm{pH}$ on the dissolution of magnetite may be explained in terms of the half decomposition reaction of hydrazine [Eq. (4)]; its oxidation potential changes can be described by the familiar Nernst equation [Eq. (5)].

$$
\begin{aligned}
& \mathrm{N}_{2} \mathrm{H}_{4} \rightarrow \mathrm{N}_{2}(g)+4 \mathrm{H}^{+}+4 e^{-} \\
& \mathrm{E}=\mathrm{E}_{\mathrm{o}}+\frac{R T}{F} \mathrm{pH}+\frac{R T}{4 F} \log \frac{\left[\mathrm{N}_{2} \mathrm{H}_{4}\right]}{\mathrm{P}_{\mathrm{N}_{2}}}
\end{aligned}
$$

where $\mathrm{E}_{0}(1.17 \mathrm{~V})$ is the standard oxidation potential of $\mathrm{N}_{2} \mathrm{H}_{4},{ }^{11)} F$ is the Faraday constant, $R$ is the gas constant, and $T$ is the absolute temperature. As expressed in Eq. (5), the oxidation potential increases with an increase in temperature, $\mathrm{pH}$, and $\left[\mathrm{N}_{2} \mathrm{H}_{4}\right]$. The observed increase in the dissolution rate can be explained via the increase in the oxidation potential of hydrazine in this system. The acidic dissolution of magnetite is negligible, and Eq. (5) is qualitatively valid within the experimental range considered. When $\mathrm{Cu}(\mathrm{I})$ ions are excluded from $\mathrm{N}_{2} \mathrm{H}_{4}-\mathrm{Cu}(\mathrm{I})-\mathrm{HNO}_{3}$, only $28 \%$ of magnetite dissolved over $6 \mathrm{~h}$ at $95^{\circ} \mathrm{C}$ at a $\mathrm{pH}$ of 3 . In a separate test, it was also found that $\mathrm{Cu}(\mathrm{I})$ ions themselves barely dissolved magnetite in $\mathrm{HNO}_{3}$.

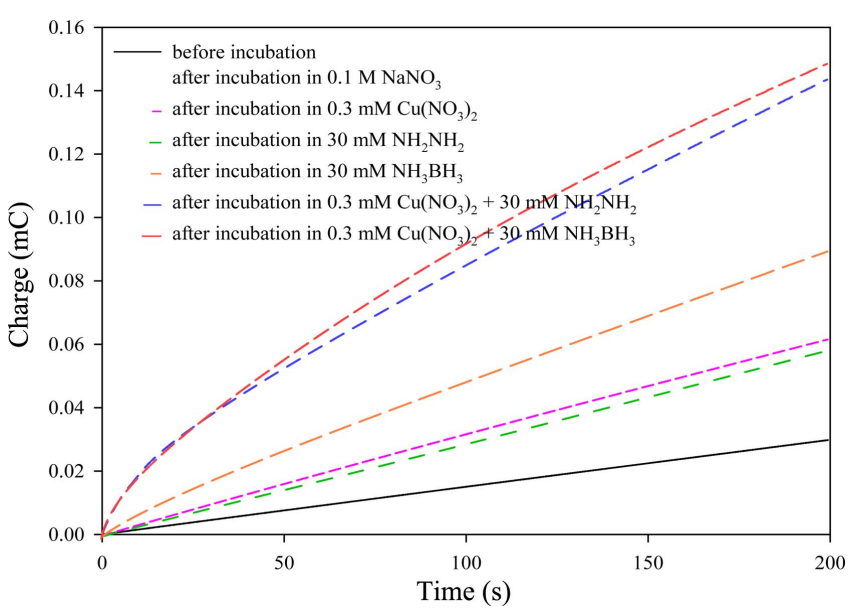

Fig. 6. Comparison of anodic charge of $\mathrm{K}_{4} \mathrm{Fe}(\mathrm{CN})_{6}$ measured from chronoamperometry.

\subsection{Identification of copper hydrazine bonding and its dissolution mechanism}

Figure 6 shows a plot of charge vs. time under various incubation conditions. The charge values were obtained by integrating the electric current values measured via chronoamperometry. $\mathrm{Fe}_{3} \mathrm{O}_{4}$ particles deposited on the surface of indium-tin oxide (ITO) were used as the working electrode. After incubation under various solution conditions, all samples exhibited an increase in charge over time. The charge of the $0.3 \mathrm{mM} \mathrm{Cu}\left(\mathrm{NO}_{3}\right)_{2}+30 \mathrm{mM} \mathrm{N} \mathrm{N}_{2} \mathrm{H}_{4}$ and $0.3 \mathrm{mM}$ $\mathrm{Cu}\left(\mathrm{NO}_{3}\right)_{2}+30 \mathrm{mM} \mathrm{NH}_{3} \mathrm{BH}_{3}$ systems increased significantly after incubation. This means that $\mathrm{Cu}^{2+}+\mathrm{N}_{2} \mathrm{H}_{4}$ and $\mathrm{Cu}^{2+}+$ $\mathrm{NH}_{3} \mathrm{BH}_{3}$ systems can dissolve $\mathrm{Fe}_{3} \mathrm{O}_{4}$ efficiently.

Figure 7 shows the FT-IR spectrum of a synthesized solidstate copper(I) hydrazine complex made from $\mathrm{N}_{2} \mathrm{H}_{4}-\mathrm{Cu}(\mathrm{I})-$ $\mathrm{HCl}$. N-H stretching frequencies were observed at 529, $1109,1249,1510,1550$, and $3200 \mathrm{~cm}^{-1}$. The N-H stretching frequency of $\mathrm{NH}_{3}^{+}$was also observed in the range of 2600$3300 \mathrm{~cm}^{-1}$. The $\mathrm{N}-\mathrm{N}$ stretching frequency observed at 960 $\mathrm{cm}^{-1}$ coincides with the $\mathrm{N}-\mathrm{N}$ stretching frequency of hydrazinium ions $\left(\mathrm{N}_{2} \mathrm{H}_{5}^{+}\right)$observed in the range of 958-965 $\mathrm{cm}^{-1}$. In particular, the $\mathrm{Cu}-\mathrm{N}$ stretching frequency was also observed at $420 \mathrm{~cm}^{-1}$. ${ }^{12)}$ The significant absorption peaks

Table 2. Stretching Frequency of Synthesized Sample

\begin{tabular}{cc}
\hline Bonding & Wavenumber $\left(\mathrm{cm}^{-1}\right)$ \\
\hline & 529 \\
& 1109 \\
$\mathrm{~N}-\mathrm{H}$ & 1249 \\
& 1510 \\
& 1550 \\
$\mathrm{~N}-\mathrm{H}\left(\mathrm{NH}_{3}{ }^{+}\right)$ & 3250 \\
$\mathrm{~N}-\mathrm{N}\left(\mathrm{N}_{2} \mathrm{H}_{5}^{+}\right)$ & $2600 \sim 3200$ \\
$\mathrm{Cu}-\mathrm{N}$ & 960 \\
\hline
\end{tabular}




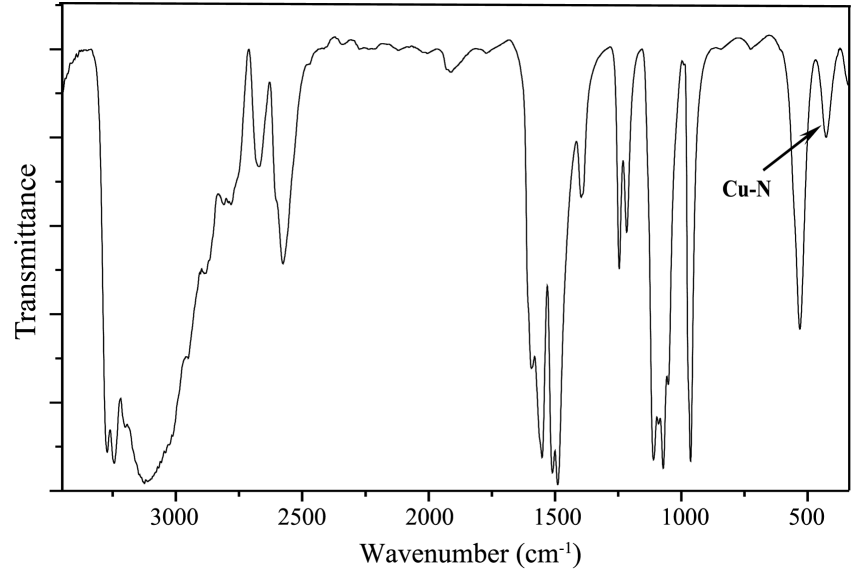

Fig. 7. FT-IR spectra of synthesized $\mathrm{N}_{2} \mathrm{H}_{4}-\mathrm{Cu}^{+}-\mathrm{HNO}_{3}$ sample.

observed and their assignments are given in Table 2.

The reaction of hydrazine with $\mathrm{Cu}$ (II) chloride in acidic solutions has been shown to produce several complexes. It was reported that hydrazine behaves as a reducing agent, leading to white, diamagnetic cuprous complexes of $\left(\mathrm{N}_{2} \mathrm{H}_{4}\right) \mathrm{CuCl}$ and black paramagnetic mixed-valence tricopper (2I, II) complexes of $\left(\mathrm{N}_{2} \mathrm{H}_{5}\right)_{2} \mathrm{Cu}_{3} \mathrm{Cl}_{6}{ }^{13)}$ Iskander et al. also reported that, at high temperatures, oxidation-reduction reactions occur between hydrazine and copper ions, yielding the formation of complexes with mixed oxidation states of copper. ${ }^{14)}$ From our FT-IR spectral analysis, we predicted that complex formation occurs between $\mathrm{Cu}(\mathrm{I})$ ions and hydrazine in $\mathrm{N}_{2} \mathrm{H}_{4}-\mathrm{Cu}(\mathrm{I})-\mathrm{HNO}_{3}$. This is related to the increase of the dissolution rate caused by the increase of $[\mathrm{Cu}(\mathrm{I})]$ under the given conditions. Hydrazine in acid solutions exists as hydrazinium ions. Because the dissolution rates of the systems under consideration are slow, $\mathrm{Cu}$ (II) ions are reduced to $\mathrm{Cu}(\mathrm{I})$ ions by the hydrazine in the acid solution during the dissolution of magnetite. In the meantime, $\mathrm{Cu}(\mathrm{I})$ ions form complexes with hydrazine. These complexes adsorbs on the surface Fe(III) ion sites of magnetite. Then, electron transfer from the complexes to Fe(III) ions occurs effectively. Fe(III) ions are reduced to $\mathrm{Fe}(\mathrm{II})$ ions and dissolve into the solution. To satisfy the electro-neutrality condition, the $\mathrm{O}^{2-}$ ions of magnetite react with $\mathrm{H}^{+}$ions and form water. The $\mathrm{Cu}$ (II) ion in the complex is reduced again to a $\mathrm{Cu}(\mathrm{I})$ ion by hydrazine. The above-described reaction scheme can be expressed as follows.

$$
\begin{aligned}
& 2 \mathrm{Cu}^{2+}+1 / 2 \mathrm{~N}_{2} \mathrm{H}_{4} \rightarrow 2 \mathrm{Cu}^{+}+2 \mathrm{H}^{+}+1 / 2 \mathrm{~N}_{2}(\mathrm{~g}) \\
& 2 \mathrm{~N}_{2} \mathrm{H}_{4}+2 \mathrm{H}^{+} \rightarrow 2 \mathrm{~N}_{2} \mathrm{H}_{5}^{+} \\
& 2 \mathrm{Cu}^{+}+2 \mathrm{~N}_{2} \mathrm{H}_{5}^{+} \rightarrow 2\left[\mathrm{Cu}^{+}\left(\mathrm{N}_{2} \mathrm{H}_{4}\right)\right]+2 \mathrm{H}^{+} \\
& 2\left[\mathrm{Cu}^{+}\left(\mathrm{N}_{2} \mathrm{H}_{4}\right)\right]+8 \mathrm{H}^{+}+\mathrm{Fe}_{3} \mathrm{O}_{4} \rightarrow \\
& \quad 2\left[\mathrm{Cu}^{2+}\left(\mathrm{N}_{2} \mathrm{H}_{4}\right)\right]+3 \mathrm{Fe}^{2+}+4 \mathrm{H}_{2} \mathrm{O} \\
& 2\left[\mathrm{Cu}^{2+}\left(\mathrm{N}_{2} \mathrm{H}_{4}\right)\right]+1 / 2 \mathrm{~N}_{2} \mathrm{H}_{4} \rightarrow 2\left[\mathrm{Cu}^{+}\left(\mathrm{N}_{2} \mathrm{H}_{4}\right)\right]+1 / 2 \mathrm{~N}_{2}+2 \mathrm{H}^{+}
\end{aligned}
$$

\subsection{Oxide film dissolution}

Figure 8 shows the amount of dissolved metal ions in the oxide film on the Inconel 600 surface vs. time during each step. When the oxidation pretreatment step was omitted, the reductive dissolution reaction was extremely slow. The reductive dissolution step was performed under a given

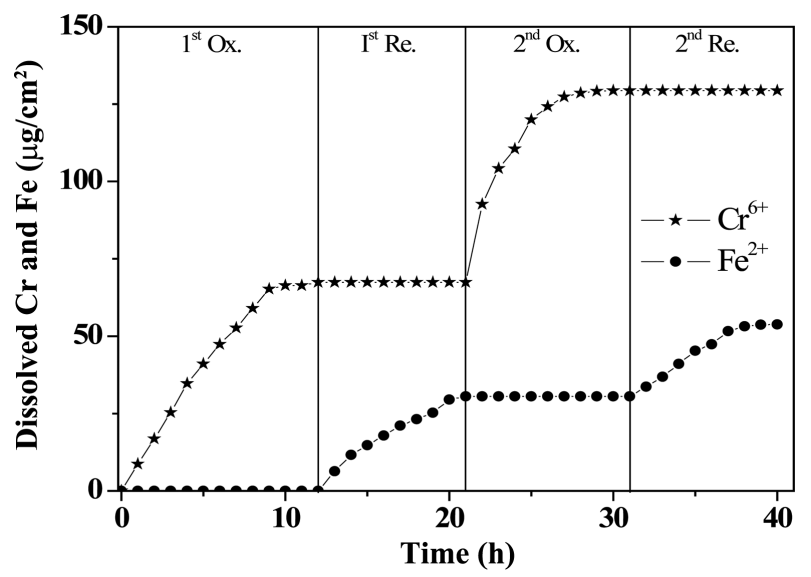

Fig. 8. Amount of dissolved metal ion from Inconel-600 oxide film against application time.

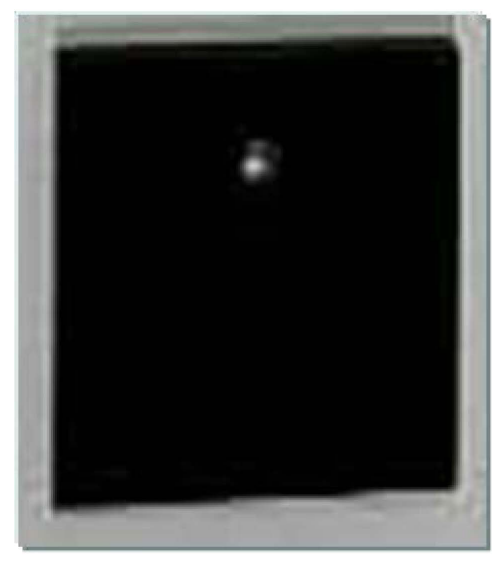

(a)

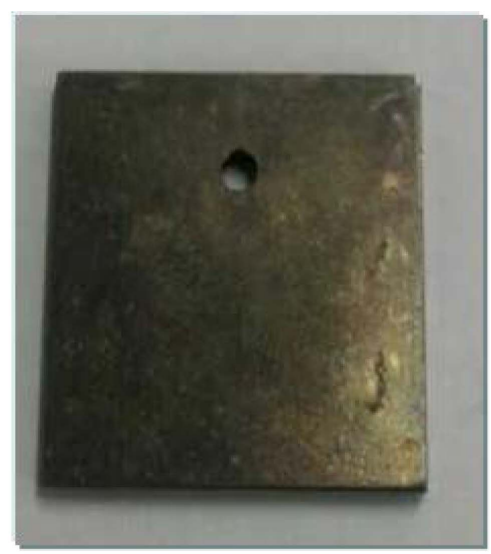

(b)

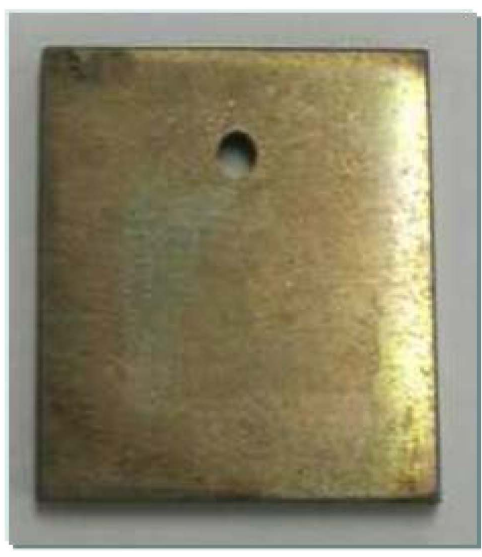

(c)

Fig. 9. Photographs of Inconel 600 specimen: (a) before, and after (b) 2nd oxidation step and (c) 2nd reductive dissolution step. 


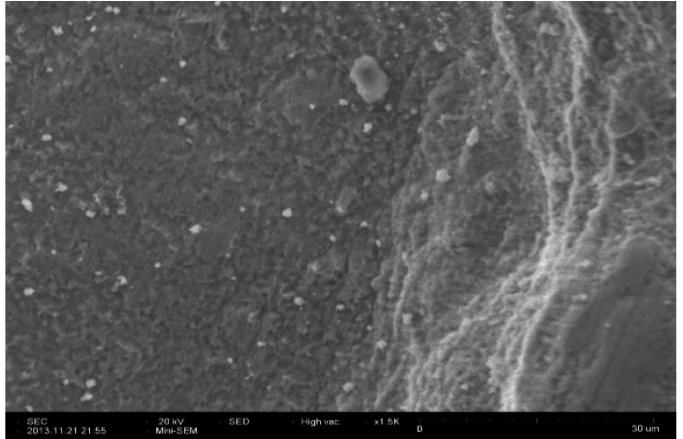

(a)

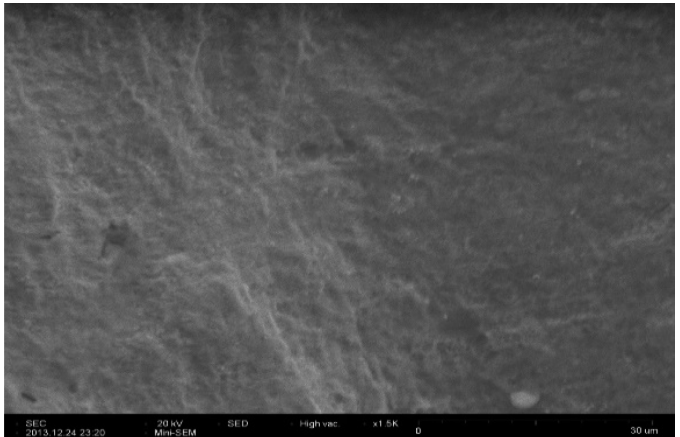

(b)

Fig. 10. SEM micrographs of Inconel 600 surface $(\times 1500)$ : (a) before and (b) after 2 nd reductive dissolution step.

concentration $\left(\left[\mathrm{N}_{2} \mathrm{H}_{4}\right]=0.04 \mathrm{M},[\mathrm{Cu}(\mathrm{I})]=5 \times 10^{-4} \mathrm{M}\right.$, and $\mathrm{pH}$ = 3) at $95^{\circ} \mathrm{C}$. As shown in Fig. 8, iron ions continuously dissolved out from the oxide film in the first reductive dissolution step over $8 \mathrm{~h}$. A total of $30.53 \mathrm{mg} / \mathrm{cm}^{2}$ of iron ions were dissolved in the first reductive dissolution step and $23.29 \mathrm{mg} / \mathrm{cm}^{2}$ of iron ions were dissolved in the second reductive dissolution step. The corrosion rate of Inconel 600, which was estimated using the weight loss method, was 1.5 $\times 10^{-5} \mathrm{mil} / \mathrm{hr}$. It was previously reported that the difference in the dissolution behaviors of magnetite powder and the oxide film can, in such cases, be attributed to the participation of the underlying base metal, which significantly promotes the kinetics of dissolution. ${ }^{15)}$ As the increase in the iron ion concentration became saturated after $8 \mathrm{~h}$, the effect of the dissolution of the base metal on the dissolution rate of the oxide film was negligible in $\mathrm{N}_{2} \mathrm{H}_{4}-\mathrm{Cu}(\mathrm{I})-\mathrm{HNO}_{3}$.

Figures 9 and 10 show images of the surface of the Inconel 600 specimen. As shown in Fig. 9, the color of the specimen before the dissolution test was black. After two cycles, the oxide layer was satisfactorily removed and the specimen exhibited a clean surface. As shown in Fig. 10, the adhered oxide particulates were fully removed and the surface of the Inconel 600 specimen was smooth.

\section{Conclusions}

The addition of copper ions to $\mathrm{N}_{2} \mathrm{H}_{4}-\mathrm{HNO}_{3}$ solutions offers a new pathway to dissolve magnetite; the main factors for dissolution can be explained by the oxidation potential changes of hydrazine and the catalytic property of copper ions. The formation of copper hydrazine complexes and its reaction pathway are suggested. The dissolution rate of magnetite particulates by $\mathrm{N}_{2} \mathrm{H}_{4}-\mathrm{Cu}(\mathrm{I})-\mathrm{HNO}_{3}$ starts to slow down as reaction time increases. This was explained via the contracting core model. Our results indicate that the solution efficiently dissolves the simulated oxide film formed on the Inconel 600 surface. Because $\mathrm{N}_{2} \mathrm{H}_{4}$ reacts with hydrogen peroxide and easily decomposes into nitrogen gas and water, the generated volume of secondary waste can be significantly reduced by destroying the decontamination agent. ${ }^{16)}$ It has already been reported that type-304 stainless- steel specimens radioactively contaminated under PWR water chemistry conditions were successfully decontaminated by $\mathrm{N}_{2} \mathrm{H}_{4}-\mathrm{Cu}^{+}-\mathrm{HNO}_{3} .{ }^{17)}$ The prepared solution also exhibited good corrosion compatibility with Inconel 600. The newly formulated dilute chemical decontamination agent, which does not use conventional organic chelates such as EDTA, NTA, citric acid, or oxalic acid, will be a good option to decontaminate the internals of nuclear power plants.

\section{Acknowledgments}

The authors would like to express their appreciation to the National Research Foundation (NRF) of Korea for the award of a grant funded by the Ministry of Science and ICT (MIST) of the Republic of Korea, in support of the authors' work through the Nuclear Research and Development Program (NRF-2017M2A8A5015144).

\section{REFERENCES}

1. B. Issa, I. M. Obaidat, B. A. Abliss, and Y. Haik, "Magnetic Nanoparticles; Surface Effects and Properties Related to Biomedicine Applications," Int. J. Mol. Sci., 14 [11] 21266-305 (2013).

2. V. S. Sathyaseelan, A. L. Rufus, P. Chandramohan, H. Subramanian, T. V. K. Mohan, and S. V. Narasimhan, "High Temperature Dissolution of Oxide Deposits Formed over Structural Materials under PHWR and BWR Chemistry Conditions," Prog. Nucl. Energy, 59 100-6 (2012).

3. L. A. G. Rodenas, M. A. Blesa, and P. J. Morando, "Reactivity of Metal Ocides: Thermal and Photochemical Dissolution of $\mathrm{MO}$ and $\mathrm{MFe}_{2} \mathrm{O}_{4}(\mathrm{M}=\mathrm{Ni}, \mathrm{Co}, \mathrm{Zn})$," J. Solid State Chem., 181 [9] 2350-58 (2008).

4. S. J. Keny, A. G. Kumbhar, G. Venkateswaran, and K. Kishore, "Radiation Effects on the Dissolution Kinetics of Magnetite and Hematite in EDTA- and NTA- Based Dilute Chemical Decontamination Formulations," Radiat. Phys. Chem., 72 [4] 475-82 (2005).

5. E. B. Borghi, A. E. Regazzoni, A. J. G. Maroto, and M. A. Blesa, "Reductive Dissolution of Magnetite by Solutions Containing EDTA and $\mathrm{Fe}^{\mathrm{II}}$," J. Colloid Interface Sci., 130 [2] 299-310 (1988). 
6. M. G. Segal and R. M. Sellers, "Reactions of Solid Iron(III) Oxides with Aqueous Reducing Agents," J. Chem. Soc. Chem. Commun., 1980 [21] 991-94 (1980).

7. E. Baumgartner, M. A. Blesa, N. Marinowich, and A. J. G. Maroto, "Heterogeneous Electrom Transfer as a Pathway in the Dissolution of Magnetite in Oxalic Acid Solutions," Inorg. Chem., 22 [16] 2224-26 (1983).

8. A. M. Al-Mayouf and A. S. N. Al-Arifi, "Reductive Dissolution of Magnetite in Ethylene-Diaminedisuccinic Acid Solutions," Desalination, 182 [1-3] 233-41 (2005).

9. V. I. E. Bruyere and M. A. Blesa, "Acidic and Reductive Dissolution of Magnetite in Aqueous Sulfuric Acid : Site Binding Model and Experimental Results," J. Electroanal. Chem. Interfacial Electrochem., 182 [1] 141-56 (1985).

10. M. Pourbaix, Atlas of Electrochemical Equilibria in Aqueous Solutions; p. 386, National Association of Corrosion Engineers, Texas, 1974.

11. J. P. Chen and L. L. Lim, "Key Factors in Chemical Reduction by Hydrazine for Recovery of Precious Metals," Chemosphere, 49 [4] 363-70 (2002).

12. A. K. Srivastava, A. L. Varshney, and P. C. Jain, "Complexes of Copper(II) with Substituted Hydrazine," J. Inorg. Nucl. Chem., 42 [1] 47-50 (1980).
13. D. B. Brown, J. A. Donner, J. W. Hall, S. R. Wilson, R. B. Wilson, D. K. Hodgson, and W. E. Hatfield, "Interaction of Hydrazine with Copper(II) Chloride in Acidic Media. Formation, Spectral and Magnetic Properties, and Structures of Copper (II), Copper (I), and Mixed-Valence Species," Inorg. Chem., 18 [10] 2635-41 (1979).

14. M. F. Iskander, S. E. Zayan, M. A. Khalifa, and L. ElSayed, "Coordination Compounds of Hydrazine Derivatives with Transition Metals- VI: The Reaction of Aroylhydrazines with Nickel (II), Cobalt (II) and Copper (II) Salts," J. Inorg. Nucl. Chem., 36 [3] 551-56 (1974).

15. A. A. M. Prince, S. Velmurugan, S. V. Narashimhan, C. Ramesh, N. Murugesan, P. S. Raghavan, and R. Gopalan, "Dissolution Behaviour of Magnetite Film Formed over Carbon Steel in Dilute Organic Acid Media," J. Nucl. Mater., 289 [3] 281-90 (2001).

17. H. J. Won, J. S. Park, C. H. Jung, S. Y. Park, W. K. Choi, and J. K. Moon, "A Reductive Dissolution Study of Magnetite"; pp. V002T03A021 in Proceedings of the $5^{\text {th }}$ ASME International Conference on Environmental Remediation and Radioactive Waste Management ICEM2013-96101, Brussels, Belgium, 2013. 